\title{
Elucidating the Beneficial Role of PPAR Agonists in Cardiac Diseases
}

\author{
Zaza Khuchua ${ }^{1,2,3, *}$, Aleksandr I. Glukhov ${ }^{2,4}$, Arnold W. Strauss ${ }^{1}$ and Sabzali Javadov ${ }^{5, *}$ \\ 1 The Heart Institute, Cincinnati Children's Hospital Medical Center, Cincinnati, OH 45229-7020, USA; \\ arnold.strauss@cchmc.org \\ 2 Department of Biochemistry, Sechenov University, 119991 Moscow, Russia; aiglukhov1958@gmail.com \\ 3 Department of Biochemistry, Ilia University, Tbilisi 0162, Georgia \\ 4 Department of Biology, Lomonosov Moscow State University, 119991 Moscow, Russia \\ 5 Department of Physiology, University of Puerto Rico School of Medicine, San Juan, PR 00936-5067, USA \\ * Correspondence: zkhuchua@gmail.com (Z.K.); sabzali.javadov@upr.edu (S.J.); \\ Tel.: +1-513-490-2206 (Z.K.); +1-787-758-2525 (ext. 2909) (S.J.)
}

Received: 20 September 2018; Accepted: 2 November 2018; Published: 4 November 2018

\begin{abstract}
Peroxisome proliferator-activated receptors (PPARs) are nuclear hormone receptors that bind to DNA and regulate transcription of genes involved in lipid and glucose metabolism. A growing number of studies provide strong evidence that PPARs are the promising pharmacological targets for therapeutic intervention in various diseases including cardiovascular disorders caused by compromised energy metabolism. PPAR agonists have been widely used for decades as lipid-lowering and anti-inflammatory drugs. Existing studies are mainly focused on the anti-atherosclerotic effects of PPAR agonists; however, their role in the maintenance of cellular bioenergetics remains unclear. Recent studies on animal models and patients suggest that PPAR agonists can normalize lipid metabolism by stimulating fatty acid oxidation. These studies indicate the importance of elucidation of PPAR agonists as potential pharmacological agents for protection of the heart from energy deprivation. Here, we summarize and provide a comprehensive analysis of previous studies on the role of PPARs in the heart under normal and pathological conditions. In addition, the review discusses the PPARs as a therapeutic target and the beneficial effects of PPAR agonists, particularly bezafibrate, to attenuate cardiomyopathy and heart failure in patients and animal models.
\end{abstract}

Keywords: PPAR agonists; bezafibrate; heart; cardiomyopathy; heart failure; lipids; fatty acid oxidation; energy metabolism; mitochondria

\section{Introduction}

Peroxisome proliferator-activated receptors (PPARs) play an important role in the regulation of carbohydrate and lipid metabolism in the cell. They are involved in the transcriptional regulation of multiple processes and play a central role in the pathogenesis of metabolic disorders, cardiovascular diseases, diabetes, cancer, inflammation, and other diseases. PPARs are members of the nuclear hormone receptor superfamily and act as ligand-activated transcription factors. They were first discovered in the early 1990s as transcription factors that mediate proliferation of peroxisomes in the cell [1-3]. Interestingly, biological effects of bezafibrate (BF), a potent pan-specific activator of PPARs, were demonstrated before cloning and discovery of PPARs [4-6]. Currently, there are three PPAR isoforms, PPAR $\alpha, \operatorname{PPAR} \beta / \delta$, and PPAR $\gamma$ that are encoded by separate genes. All three isoforms possess a high degree of inter-species sequence homology, particularly in the DNA-binding domain (DBD) and ligand-binding domain (LBD) [7,8] (Figure 1). The central role of PPARs in heart metabolism, 
particularly fatty acid oxidation (FAO) and mitochondrial bioenergetics, makes them a promising therapeutic target for the treatment of cardiac diseases, such as myocardial infarction (MI) and heart failure (HF). A growing number of studies using experimental animal models and patients often provide controversial data on the beneficial effects of PPAR agonists in cardiac diseases. In this review, we summarize and discuss the role of PPARs, particularly PPAR $\alpha$, in the healthy heart and cardiac diseases. In addition, we provide a comprehensive discussion of PPAR agonists in the treatment of cardiac diseases, particularly cardiomyopathy and HF.

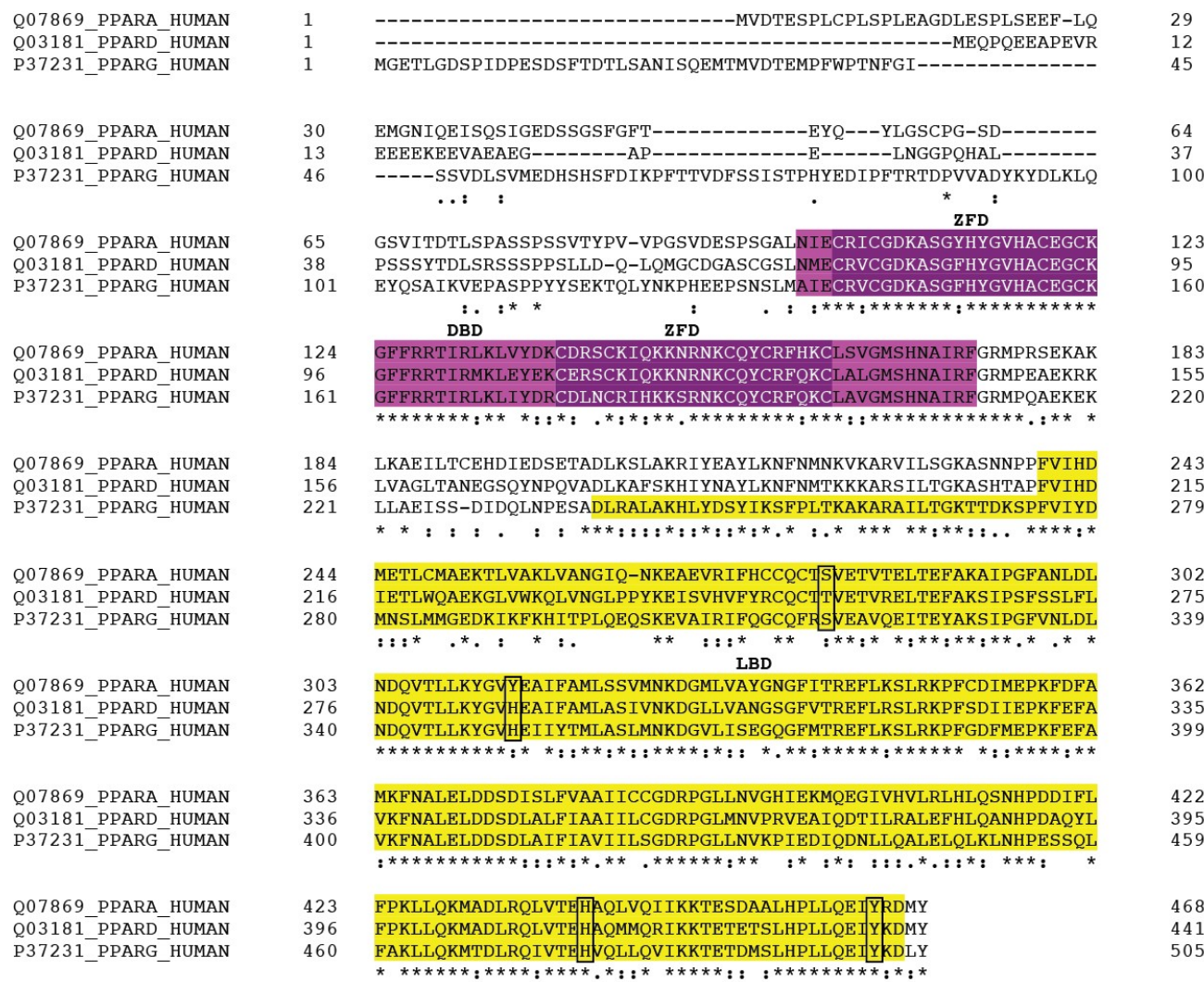

Figure 1. Amino acid sequence alignments of human peroxisome proliferator-activated receptors (PPAR) isoforms. DNA-binding domain (DBD, purple), zinc-finger domains (ZFD, purple), and ligand binding domain (LBD, yellow) are highlighted. All three isoforms of PPAR possess a high degree of inter-species sequence homology, particularly in the DBD and LBD. The sequence positions that are conserved within PPAR isoforms are important for identification of the structural dynamics, ligand affinity, and DNA binding specificity. Amino acid residues, which participate in ligand binding, are boxed. Alignment was performed with CLUSTALO (https:/ / www.uniprot.org/align/). $\left({ }^{*}\right.$ —-fully conserved residues; (:)—residues with strongly similar properties; (.)—residues with weakly similar properties.

\section{Biological Role and Tissue-Specific Expression of PPARs}

PPARs form heterodimers with the retinoid $X$ receptor in the nucleus. These heterodimers recruit coactivators and corepressors and bind to specific peroxisome proliferator response elements (PPRE) in regulatory regions of PPAR target genes (Figure 2). Ligand binding releases the corepressor from the complex and allows activation of coactivator leading to changes in target gene expression [9]. DNA-pull down of PPAR $\gamma$ with subsequent MS-based proteomics identification of binding partners revealed highly complex patterns of interaction of PPAR $\gamma$ with other proteins in the cytoplasm and nucleus [10]. In addition, this study revealed that interactions of PPAR $\gamma$ with its binding partners are highly ligand- and DNA-dependent. In silico analysis of protein-protein interactions between PPAR $\alpha$ and PPAR $\beta / \delta$ predicted the interaction of PPARs 
and retinoid X receptors (RXRs) with chromatin state modifiers, such as histone deacetylases (HDACs) that can play a role in epigenetic modifications of the diseases [11].

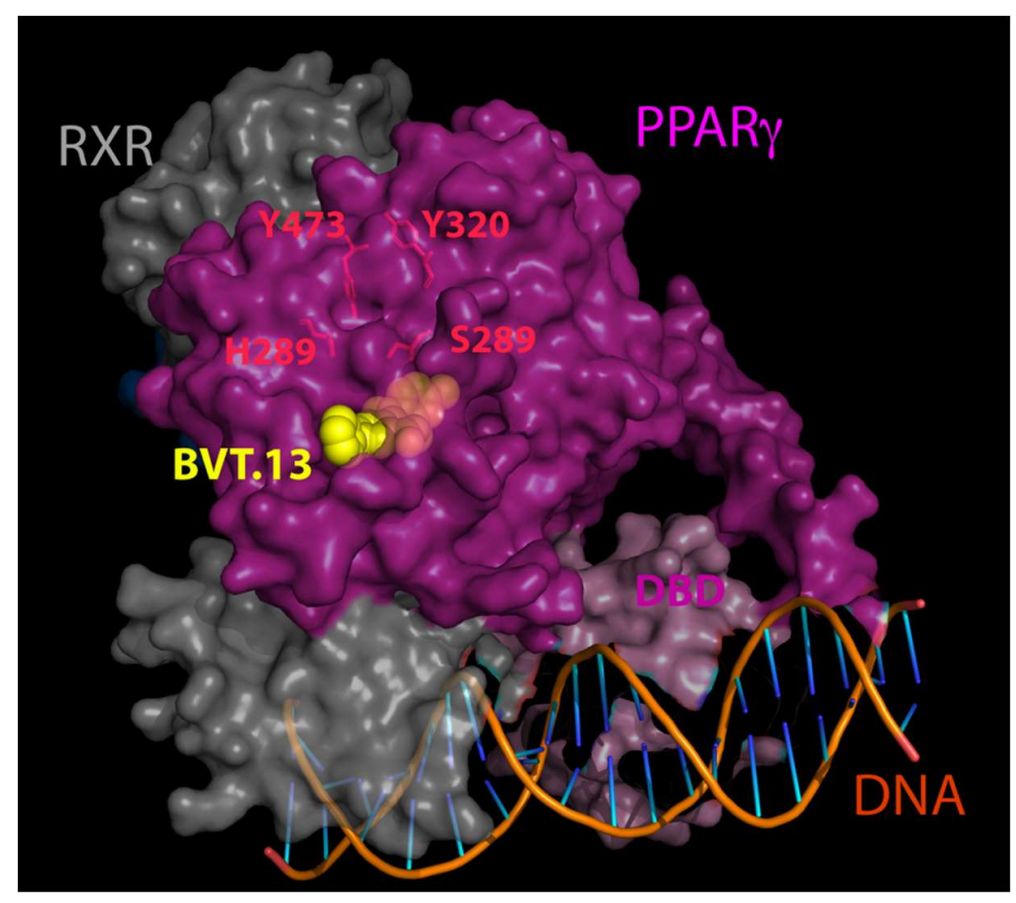

Figure 2. X-ray crystal structure of the complex of PPAR $\gamma$ (magenta) and retinoid X receptors (RXR) (grey) at $3.2 \AA$ resolution. The BVT.13 agonist ligand is displayed as yellow balls. The amino acids residues, which form a ligand binding pocket, are shown in red. DNA-binding domain (DBD, light magenta) and DNA fragment are shown. The structure is derived from Protein Data Bank (PDB: 3DZU) [12] and visualized using PyMol software (v. 2.0.7).

PPAR $\alpha$ plays a crucial role in the regulation of FAO, a major source of ATP in high energy-consuming organs and tissues. Hence, PPAR $\alpha$ is highly expressed in skeletal muscle, heart, liver, and brown adipose tissue [13-15]. PPAR $\gamma$ is mainly expressed in adipose tissue, large intestine, and spleen. It regulates adipogenesis, lipid and glucose metabolism, and inflammatory pathways. The least studied PPAR $\beta / \delta$ is expressed ubiquitously with the highest levels found in the liver, intestine, kidney, adipose tissue, and skeletal muscle thereby, suggesting its fundamental role in cellular biology (reviewed in References [16-19]).

Transcriptional activities of PPARs are regulated, in part, by the PPAR $\gamma$ coactivator $1 \alpha$ (PGC- $1 \alpha$ ). PGC- $1 \alpha$ is an integrator of the transcriptional network regulating mitochondrial biogenesis and, like PPAR $\alpha$, highly expressed in high energy-consuming cells. In addition to PPARs, PGC- $1 \alpha$ mediates its effects through other downstream transcriptional regulatory circuits such as estrogen-related receptors (ERRs), and nuclear respiratory factors (NRF) 1 and 2. The nuclear respiratory factors, in turn, regulate downstream genes, including mitochondrial transcription factor A (TFAM), which is responsible for the maintenance as well as replication and transcription of mitochondrial DNA (reviewed in References [20-22]). Thus, PGC-1 $\alpha$ is an inducible co-activator that coordinately regulates mitochondrial biogenesis through the network of transcription factors PPARs/NRF/ERRs. Mitochondrial biogenesis via the PGC- $1 \alpha /$ NRF pathway is apparently regulated by AMP kinase (AMPK) $[23,24]$. Indeed, direct phosphorylation of PGC-1 $\alpha$ by AMPK in vitro and in cultured cells has been shown recently [25].

Various natural fatty acids and eicosanoids act as natural ligands for PPARs. Generally, polyunsaturated fatty acids (PUFAs) display a higher affinity to PPAR $\gamma$ and PPAR $\beta / \delta$, while both saturated and unsaturated fatty acids interact with PPAR $\alpha$ equally efficiently (reviewed in Reference [8]). Therefore, PPARs represent attractive molecular targets for the development of pharmacological agents and treatment of metabolic disorders, including obesity, type 2 diabetes, dyslipidemia, and cardiovascular diseases. 


\section{The Role of PPARs in Cardiac Diseases}

PPAR $\alpha$ is highly expressed in cardiomyocytes, and genetic studies demonstrated the importance of PPAR $\alpha$ in fatty acid metabolism in the heart [26,27]. PPAR $\alpha$ knockout mice demonstrated normal [27] or reduced [26,28] cardiac function. Cardiac dysfunction in PPAR $\alpha^{-/-}$mice was associated with structural abnormalities in mitochondria [26] and increased oxidative stress due to downregulation of the antioxidant capacity in the heart [29]. High workload decreased cardiac performance in PPAR $\alpha$ knockout mice associated with lower levels of ATP in the myocardium [30]. In response to transverse aortic constriction (TAC), PPAR $\alpha$-null mice showed pronounced cardiac hypertrophy [31]. On the other hand, overexpression of PPAR $\alpha$ increased mild cardiac hypertrophy, ventricular dysfunction, and lipotoxicity associated with reciprocal repression of glucose uptake and oxidation in the mouse heart [32]. These mice developed a phenotype strikingly similar to diabetic cardiomyopathy [33]. The contrasting metabolic phenotypes induced by genetic upregulation or downregulation of PPAR $\alpha$ in mice indicate the central role of the receptors in regulating glucose and lipid metabolism in the heart.

Recent studies demonstrated that the expression of PPAR $\alpha$ significantly decreases in cardiomyocytes in a pressure-overload mouse model of HF induced by TAC. Expression of PPAR $\alpha$ target genes, carnitine palmitoyltransferase 1 (CPT-1) and fatty acid transport protein 1 (FATP1) were also significantly reduced in the HF hearts. Activation of PPAR $\alpha$ either by cardiac-specific overexpression of PPAR $\alpha$ gene or by treating mice with the specific PPAR $\alpha$ agonist, WY-1463 improved cardiac function, attenuated cardiac fibrosis, and preserved FAO and high-energy phosphates in a mouse model of HF induced by TAC [34]. The energy substrate switch from FAO to glucose oxidation and other metabolic changes in hearts with hypertrophy and HF is mediated, at least in part, through downregulation of genes encoding FAO and oxidative phosphorylation enzymes due to deactivation of the PGC- $1 \alpha /$ PPAR $\alpha$ pathway [21,22]. Reduced PGC- $1 \alpha$ and PPAR $\alpha$ expression occurs in animal models of $\mathrm{HF}[35,36]$ and in failing human hearts $[37,38]$, suggesting that deactivation of the PGC- $1 \alpha /$ PPAR $\alpha$ pathway in the failing heart plays a critical role in coincident mitochondrial dysfunction.

The role of post-translational modifications (PTMs) in activation/inactivation of PPAR $\alpha$ is debated. PPARs have been shown to undergo several types of PTMs including phosphorylation, acetylation, sumoylation, and ubiquitination, among others. Several protein kinases, including extracellular signal-regulated protein kinases 1 and 2 and c-Jun N-terminal kinase, AMPK, protein kinase A, and glycogen synthase kinase 3 phosphorylate PPAR $\alpha$ and PPAR $\gamma$ [39]. Protein kinase A [40] and p38 [41] phosphorylated PPAR $\alpha$ that resulted in a ligand-dependent increase of PPAR $\alpha$ activity in neonatal rat cardiomyocytes and HEK-293 cells. On the other hand, ventricular pressure overload in mice and PPAR $\alpha$ overexpression in cardiomyocytes revealed that downregulation of cardiac PPAR $\alpha$ and alteration of its activity during hypertrophic growth occur at the posttranscriptional level via activation of extracellular signal-regulated protein kinases 1 and 2 [42]. Phosphorylation increased transcriptional activation of PPAR $\alpha$ [43] but decreased that of PPAR $\gamma$ [44].

PPAR $\alpha$ seems to be a downstream target for AMPK and mediates its beneficial effects by improving mitochondrial metabolism. AMPK is the main cellular energy sensor that initiates ATP generating processes while blocking ATP consuming processes. It is also involved in the regulation of mitochondrial metabolism and the redox state in the cell (reviewed in References [45,46]). Pharmacological activation of AMPK stimulates FAO through increased expression of PPAR $\alpha$ target genes in skeletal muscle cells [47]. Furthermore, the PPAR $\alpha$ inhibitor, GW6471, prevented the cardioprotective effects of metformin, an AMPK activator, against ischemia-reperfusion in rat hearts [48]. Oxidative stress-induced phosphorylation of PGC- $1 \alpha$ and PPAR $\alpha$ in cardiac cells. However, the protective effects of the AMPK activators metformin and A-769662 on hydrogen peroxide-treated $\mathrm{H} 9 \mathrm{c} 2$ cells and in vivo cardiac ischemia-reperfusion in rats were not associated with phosphorylation of PPAR $\alpha[49,50]$. These studies suggest that PTMs of PPAR $\alpha$ during cardiac oxidative stress and hypertrophic growth can occur at several levels. 
In addition to regulation of the mitochondrial transcriptional network, PPAR $\alpha$ can translocate to mitochondria and affect metabolism and function of mitochondria. Hydrogen peroxide-induced oxidative stress in $\mathrm{H9c} 2$ cells [49] and ischemia-reperfusion in the rat heart [50] stimulated protein-protein interactions between PPAR $\alpha$ and cyclophilin D (CyP-D), a major regulator of the mitochondrial permeability transition pore. The interaction provoked the opening of the mitochondrial permeability transition pores. Conversely, activation of AMPK with metformin or A-769662 prevented PPAR $\alpha$-CyP-D interaction leading to inhibition of mitochondrial permeability transition pore opening, and improved cell survival and post-infarction recovery [49,50]. These studies indicate the role of PPAR $\alpha$ in mediating the beneficial effects of AMPK in cardiac ischemia-reperfusion.

Similar to PPAR $\alpha$, heart-specific PPAR $\gamma$ knockout mice developed cardiac hypertrophy with preserved normal cardiac metabolism and function [51,52]. Decreased expression of genes encoding FAO enzymes and impaired fatty acid utilization with unchanged glucose oxidation were found in inducible cardiomyocyte-specific PPAR $\gamma^{-/-}$mice [53]. It should be noted that cardiac hypertrophy in heart-specific PPAR $\gamma$ knockout mice associated with oxidative damage and mitochondrial dysfunction progresses with age and leads to dilated cardiomyopathy and premature death [54]. Like PPAR $\alpha^{-/-}$ mice, antioxidant therapy attenuated cardiac dysfunction in the PPAR $\gamma^{-/-}$mice. Heart-specific PPAR $\gamma$ overexpression induced a dilated cardiomyopathy associated with increased expression of FAO genes, lipotoxicity, and mitochondrial structural abnormalities such as cristae disruption in the heart [55]. Interestingly, glucose uptake was not decreased in these hearts.

Overexpression of PPAR $\beta / \delta$ in mouse hearts enhanced mitochondrial biogenesis, myocardial oxidative metabolism, improved cardiac performance, and reduced cardiac fibrosis [56]. These effects of PPAR $\beta / \delta$ overexpression were not affected by TAC-induced cardiac hypertrophy. In rats with congestive HF, the PPAR $\beta$ / $\delta$-specific agonist, GW610742X, normalized cardiac substrate metabolism in a dose-dependent manner, dramatically reduced right ventricular hypertrophy, and decreased the level of the arterial natriuretic peptide in the right ventricle. However, GW610742X had no beneficial effect on the left ventricular function $[57,58]$.

The activity of a large number of proteins is regulated through acetylation/deacetylation of lysine residues. Four classes of HDACs play a central role in cell metabolism, including energy metabolism in the heart. Mitochondrial bioenergetics including fatty acid metabolism, electron transfer chain, and oxidative phosphorylation are regulated by the class III HDACs sirtuins, particularly SIRT3 [59]. Interestingly, the interaction of HDAC 3 with PPAR $\gamma$ induced deacetylation of the protein and reduced its activity [60]. Inhibition of HDAC3 stimulated ligand-independent activation of PPAR $\gamma$ by protein acetylation suggesting that acetylation of PPAR $\gamma$ induces its activation through a ligand-independent mechanism. Cardiac-specific HDAC3 knockout mice demonstrated a modest increase in expression of FAO genes with no changes in gene expression of PPARs [61]. Oxidative stress induced by hydrogen peroxide did not increase acetylation of PGC- $1 \alpha$ and PPAR $\alpha$ in H9c2 cardioblasts [49]. Further studies are needed to establish a cause-effect relationship between acetylation and activity of PPARs in the healthy heart and cardiac diseases.

Other forms of PTM, such as sumoylation [62] and ubiquitination [63], have been shown to affect the PPAR activity (reviewed in Reference [58]). These studies were conducted mostly using various cell lines, and there are few, if any, studies on the PPAR sumoylation and ubiquitination in the heart. For instance, upregulation of the ubiquitin ligase, muscle ring finger- 1 increased its interaction and ubiquitination of PPAR $\alpha$ in neonatal cardiomyocytes [64]. The ubiquitination reduced PPAR $\alpha$ activity and FAO suggesting a critical role of ubiquitination in regulating cardiac PPAR $\alpha$ and fatty acid metabolism in the heart.

Polymorphisms in PPARs are significantly associated with cardiac disorders. Intronic rs4253778 polymorphism and common L162V (rs1800206) polymorphism in PPAR $\alpha$ are significantly associated with coronary heart disease (CHD) risk [65]. L162V variant at the DBD region of PPAR $\alpha$ affects the transactivation activity of PPAR ligands [66,67]. A Rs135551 intronic variant in PPAR $\alpha$ showed significant association with CHD [68]. T allele carriers of C161T polymorphism in PPAR $\gamma$ (rs3856806) 
have lower CHD risk, but higher risk of acute coronary syndrome (ACS). $+294 \mathrm{~T} / \mathrm{C}$ polymorphism at $P P A R \gamma / \delta$ (rs2016520) is significantly associated with ACS [65].

Thus, PPARs play an important role in fatty acid metabolism in the heart and are involved in the pathogenesis of cardiac hypertrophy, cardiomyopathy, and HF. Apparently, beneficial or detrimental effects of PTMs of PPAR $\alpha$ depend on the severity and timing of oxidative and energy stresses that are associated with the diminished capacity of the myocardium to maintain lipid and glucose metabolism.

\section{Therapeutic Potential of PPAR Agonists in Cardiac Diseases}

\subsection{Studies in Animal Models}

Lower rates of FAO are associated with cardiomyopathies and HF [69-73]. Due to high expression and the beneficial role of PPAR $\alpha$ and PPAR $\beta / \delta$ in the heart, numerous studies have been conducted to study the efficiency of PPAR $\alpha$ and PPAR $\beta / \delta$ agonists on various animal models with HF.

Fibrates have been used for many years as PPAR agonists for treatment heart attacks and strokes. The fibrates are a family of hypolipidemic drugs that are structural derivatives of the parent compound, clofibrate (ethyl 2-(4-chlorophenoxy)-2-methylpropionate (Figure 3). They lower serum triglycerides, raise high-density lipoprotein cholesterol (HDL-C) and lower low-density lipoprotein cholesterol (LDL-C) levels. Therefore, long-term therapy with fibrates could help to prevent cardiovascular disease events. However, fibrates demonstrate a high risk for developing rhabdomyolysis and renal failure (reviewed in Reference [74]). The main list of fibrates currently used in experimental studies and clinical trials include gemfibrozil, fenofibrate, BF, etofibrate, and ciprofibrate (Figure 3). The clofibrate previously used in studies is no longer in use due to safety concerns.<smiles>Cc1ccc(C)c(OCCCC(C)(C)C(=O)O)c1</smiles>

Gemfibrozil<smiles>CC(C)OC(=O)C(C)(C)Oc1ccc(C(=O)c2ccc(Cl)cc2)cc1</smiles>

Fenofibrate<smiles>CCOC(=O)OC(=O)OC(C)(C)C(=O)Oc1ccc(CCNC(=O)c2ccc(Cl)cc2)cc1</smiles><smiles>CC(C)(OCCOC(=O)c1cccnc1)C(=O)Oc1ccc(Cl)cc1</smiles>

Etofibrate<smiles>CCOCCOC(C)(OCC)C(=O)Oc1ccc(C2CC2Cl)cc1</smiles><smiles>CCOC(=O)C(C)(C)Oc1ccc(Cl)cc1</smiles>

Clofibrate

Figure 3. Chemical structures of fibrates.

Fenofibrate is a dual activator of PPAR $\alpha$ and PPAR $\gamma$, with 10-fold selectivity for PPAR $\alpha$ [18]. Oral intake of fenofibrate $(100 \mathrm{mg} / \mathrm{kg}$ body weight) significantly attenuated end-diastolic and end-systolic left ventricular dimensions and cardiac fibrosis in aldosterone-induced hypertrophy model independently of an effect of the drug on blood pressure [75]. Similar effects were observed in porcine and canine tachycardia-induced cardiomyopathy models [76,77]. Fenofibrate attenuated hypertrophy, inhibited the inflammatory response, improved the survival of Dahl salt-sensitive rats [78] and decreased fibrosis in the rat model with the pressure overload-induced HF [79]. While fenofibrate had clear beneficial effects in wild-type mice, this drug had deleterious consequences on cardiac 
hypertrophy and fibrosis in PPAR $\alpha^{-/-}$mice [80]. The detrimental effects of fenofibrate in PPAR $\alpha$ knockout mice might be a result of anomalous activation of PPAR $\gamma$ and PPAR $\beta / \delta$ in cardiomyocytes in the absence of PPAR $\alpha$. Administration of another PPAR $\alpha$ agonist, tetradecylthioacetic acid, elevated expression of PPAR $\alpha$ target genes, myocardial oxygen consumption, and FAO with concomitant reduction of glucose oxidation in the heart. However, this drug had a negative impact on the post-ischemic recovery of cardiac function in an isolated perfused heart model [81].

Fibrates require micromolar concentrations to activate PPAR $\alpha$. The half maximal effective concentration $\left(\mathrm{EC}_{50}\right)$ for fenofibrate is approximately $30 \mu \mathrm{M}$ for human PPAR $\alpha$ [18] that requires high doses of the drug $(>100 \mathrm{mg} / \mathrm{kg})$ to achieve a clinical effect. Attempts to discover more potent and more selective PPAR $\alpha$ agonists resulted in the synthesis of several more potent compounds that work in nanomolar ranges. The PPAR $\alpha$ agonist AVE8134 has a high affinity for PPAR $\alpha$ $\left(\mathrm{EC}_{50} 0.01\right.$ and $0.03 \mu \mathrm{M}$ for human and rodent PPAR $\alpha$, respectively). AVE8134 at the daily dose of 3-30 mg/kg improved lipid profile and augmented glucose metabolism; prevented post-MI hypertrophy, fibrosis and cardiac dysfunction, and reduced mortality in rats [82,83]. Other selective PPAR $\alpha$ agonists, WY-14643 (pirinixic acid) and GW7647, have $\mathrm{EC}_{50}$ in the micromolar range. WY-14643 $(0.01 \% w / w$ in rodent food, or $\sim 20 \mathrm{mg} / \mathrm{kg})$ significantly attenuated cardiac dysfunction and remodeling induced by pressure-overload HF in mice [84].

Treatment with GW7647 did not prevent the development of hypertrophy but preserved the left ventricular ejection fraction during pressure-overload cardiac hypertrophy in rabbits [85]. The effects of GW7647 were associated with an increased cardiac FAO and overall ATP production that resulted in an improved post-ischemic recovery of cardiac function. In addition, GW7647 treatment resulted in relived endoplasmic reticulum stress, preserved mitochondrial membrane potential, and activated sarcoplasmic reticulum Ca-ATPase (ATP2A2) [85]. Additionally, GW2331 and GW9578, dual PPAR $\alpha /$ PPAR $\gamma$ agonists that work in the nanomolar range, have been synthesized $[86,87]$.

Bezafibrate was introduced as a lipid-lowering drug by Boehringer Mannheim in 1970s [6,88]. It reduces heart rate, blood pressure, insulin level, and free fatty acids in patients with hypertriglyceridemia [89]. Bezafibrate also is a widely used pan-PPAR agonist in animal trials. It activates all three PPAR subtypes with the highest affinity for PPAR $\alpha$ and PPAR $\beta / \delta$ isoforms [90]. The $\mathrm{EC}_{50}$ s for BF are 50, 60, and $20 \mu \mathrm{M}$ for human PPAR $\alpha, \operatorname{PPAR} \gamma$, and $\operatorname{PPAR} \beta / \delta$, respectively; and 90, 55 , and $110 \mu \mathrm{M}$ for mouse PPAR $\alpha, \operatorname{PPAR} \gamma$, and $\operatorname{PPAR} \beta / \delta$, respectively [18]. There are significant inconsistencies in BF studies in humans and rodents. In clinical practice, BF is typically prescribed at a daily dose of $10-25 \mathrm{mg} / \mathrm{kg}[6,91,92]$. Conversely, in animal studies BF is usually administrated per os with diet in the amount of $0.5 \% w / w$, corresponding to a daily dose of $600-800 \mathrm{mg}$ per $\mathrm{kg}$ [93-95]. It is conceivable that the relatively low affinity of $\mathrm{BF}$ for murine PPAR $\beta / \delta$ requires a higher dose of the drug to achieve a biological response in mice, particularly in skeletal muscle, where the BF effects are predominantly mediated by PPAR $\beta / \delta$ rather than PPAR $\alpha$ [96].

Experiments with PPAR $\alpha$ knockout mice suggested that more clinically relevant, low-dose $B F$ decreases serum and liver triglycerides in a PPAR-independent manner by suppressing the expression of sterol regulatory element-binding protein 1c (SPREBP1) affecting hepatic lipogenesis and triglyceride secretion [97]. Several groups have reported on the use of BF in mouse models with varying success. Two mouse models of cytochrome $c$-oxidase deficiency, systemic Surf1 ${ }^{-1-}$ and muscle-specific Cox15 $1-$, were given BF at the dose of $0.5 \%$ in rodent diet (Table 1 ). At this dose, BF was highly toxic, causing massive apoptosis in skeletal muscles. In these models, BF induced expression of the genes encoding proteins that are involved in FAO but not oxidative phosphorylation in mitochondria.

PPARs and PGC- $1 \alpha$ regulate mitochondrial aerobic metabolism, acting on different, though partially overlapping sets of genes. PPARs regulate expression of FAO genes, including CD36/FAT, ACOX, SCAD, while PGC-1 $\alpha$ controls the expression of genes involved in oxidative phosphorylation. Treatment with BF of Surf1 ${ }^{-/-}$mice increased expression of the PPAR isoforms present in the skeletal muscle, PPAR $\alpha$ and PPAR $\beta / \delta$. However, no increase in PGC- $1 \alpha$ was 
observed in the skeletal muscles of BF-treated mice [98]. On the contrary, BF increased mitochondrial biogenesis and significantly increased expression of PGC- $1 \alpha$ and battery of downstream its targets cytochrome c, TFAM, and subunits of ATP synthase in muscle, brown adipose tissue (BAT), and brain in mice with Huntington disease [99]. Treatment with BF rescued neuropathological features in the brain, increased motor activity, and muscle strength, prevented fiber-type switching in muscles, attenuated vacuolization in BAT and increased survival rate in Huntington mice. BF also was found to interact with hemoglobin and lower its affinity to oxygen. However, it is not clear whether the pharmacological doses of BF can achieve a concentration of the drug in erythrocytes sufficient to benefit the oxygen transport capacity $[100,101]$.

Table 1. Bezafibrate trials using mouse genetic models with mitochondrial defects.

\begin{tabular}{|c|c|c|c|c|}
\hline Disease Model & Tissue Studied & BF Dose & Effects & Ref. \\
\hline OXPHOS defect: Surf1 ${ }^{-/-}$ & Muscle & $\begin{array}{c}0.5 \% \\
(0.6-0.8 \mathrm{~g} / \mathrm{kg})\end{array}$ & $\begin{array}{l}\text { Weight loss, hepatomegaly. Increased } \\
\text { expression of FAO genes, PPAR } \alpha \text { and } \\
\text { PPAR } \beta / \delta \text {. }\end{array}$ & [98] \\
\hline OXPHOS defect: Cox $15^{-/-}$ & Muscle & $\begin{array}{c}0.5 \% \\
(0.6-0.8 \mathrm{~g} / \mathrm{kg})\end{array}$ & $\begin{array}{l}\text { Toxic, mitochondrial myopathy, } \\
\text { excessive apoptosis. }\end{array}$ & [98] \\
\hline $\begin{array}{l}\text { Huntington disease: } \\
\text { Htt-ex1 (R6/2) }\end{array}$ & $\begin{array}{l}\text { Brain, } \\
\text { Muscle, } \\
\text { BAT }\end{array}$ & $\begin{array}{c}0.5 \% \\
(0.6-0.8 \mathrm{~g} / \mathrm{kg})\end{array}$ & $\begin{array}{l}\text { Attenuated neurodegeneration in } \\
\text { brain, prevented muscle-type } \\
\text { switching. } \\
\text { Increased exercise capacity and } \\
\text { muscle strength, increased } \\
\text { vacuolization in BAT, and extend } \\
\text { survival. }\end{array}$ & [99] \\
\hline $\begin{array}{c}\text { Premature aging: } \\
\text { mtDNA polymerase } \gamma^{-/-}\end{array}$ & $\begin{array}{l}\text { Skin, } \\
\text { Spleen }\end{array}$ & $\begin{array}{c}0.5 \% \\
(0.6-0.8 \mathrm{~g} / \mathrm{kg})\end{array}$ & $\begin{array}{l}\text { Delayed hair loss and restored skin } \\
\text { structure. } \\
\text { Improved spleen size and structure. }\end{array}$ & [93] \\
\hline $\begin{array}{c}\text { BTHS: } \\
\text { TAZ knockdown }\end{array}$ & Heart & $\begin{array}{c}0.5 \% \\
(0.6-0.8 \mathrm{~g} / \mathrm{kg})\end{array}$ & $\begin{array}{l}\text { Preserved cardiac systolic function. } \\
\text { Reduced cardiolipin level in } \\
\text { mitochondria. }\end{array}$ & [95] \\
\hline $\begin{array}{c}\text { BTHS: } \\
\text { TAZ knockdown }\end{array}$ & $\begin{array}{l}\text { Heart, } \\
\text { Muscle }\end{array}$ & $\begin{array}{c}0.05 \% \\
(0.06-0.08 \mathrm{~g} / \mathrm{kg})\end{array}$ & $\begin{array}{l}\text { Restored cardiac systolic function. } \\
\text { Ameliorated exercise intolerance } \\
\text { phenotype when treatment was } \\
\text { combined with everyday voluntary } \\
\text { exercise. }\end{array}$ & [102] \\
\hline
\end{tabular}

Recent studies demonstrated the therapeutic effectiveness of BF to attenuate left-ventricular defects in the mouse model of Barth syndrome (BTHS). Barth syndrome is an X-linked rare genetic disease that is manifested by dilated cardiomyopathy, muscle weakness, and exercise intolerance. Causative gene is $T A Z$ that encodes mitochondrial cardiolipin transacylase, tafazzin, and mutations in TAZ results in a deficiency of the essential mitochondrial phospholipid cardiolipin. Intake of $\mathrm{BF}$ with diet during the 4-month period in daily doses of $60-80 \mathrm{mg} / \mathrm{kg}(0.05 \%$ in rodent diet) or $600-800 \mathrm{mg} / \mathrm{kg}(0.5 \%$ in rodent diet) effectively prevented the development of systolic dysfunction and cardiomyopathy in TAZ knockdown mice [95,102]. Surprisingly, improvement of systolic function in mice treated with a high-dose $(0.5 \%)$ of BF was accompanied by a simultaneous reduction of cardiolipin in the heart that can be explained by an increased number of mitochondria with a reduced content of cardiolipin [95].

Differential transcriptomic analysis of hearts demonstrated that treatment with a low dose $(0.05 \%)$ of BF resulted in robust activation of genes involved in a wide-spectrum of biological processes that included metabolism of fatty acids, ketone bodies, amino acids and glucose, metabolism of proteins, mitochondrial protein transport, RNA metabolism, gene expression, DNA repair, chromatin organization, immune system, and organelle biogenesis and maintenance [102]. Bezafibrate failed to ameliorate the exercise intolerance phenotype in BTHS mice. However, when treatment with BF was combined with voluntary daily exercise on the running wheel, BF's effect on exercise capacity in BTHS mice was significantly potentiated. The mechanisms underlying this synergistic effect of BF with everyday voluntary exercise are unclear. Apparently, exercise alters the epigenetic landscape 
in skeletal muscles and facilitates transcription of PPAR target genes thereby enhancing cellular metabolic plasticity.

\subsection{Clinical Studies}

Currently, 41 clinical trials are registered to investigate the therapeutic efficiency of numerous PPAR agonists in various diseases worldwide (www.clinicaltrials.gov). Among those, eight trials have been completed, and no serious adverse effects have been reported. Among 41 trials, 13 are aimed to elucidate the efficacy of PPAR agonists in cardiac diseases. To date only one phase- 2 clinical trial investigating the therapeutic potential of PPAR $\gamma$ agonist rosiglitazone in patients with congestive HF has been completed (NCT00064727), however, findings have not yet been reported.

Recently, comprehensive systemic research of major cardiovascular disease prevention trials with fibrates was performed $[103,104]$. In these trials, data associated with the effects of clofibrate, which is no longer in use, were excluded from the analysis. Moderate-quality evidence from six primary prevention trials with 16,135 participants (8087 in the intervention group and 8048 in the placebo group) suggested that fibrate therapy reduced the combined outcome of death due to cardiovascular disease, heart attack, or stroke by $16 \%$ [103].

The Bezafibrate Infarction Prevention (BIP) study was initiated in 1998 with a total of 3090 enrolled participants (1548 in the intervention group, 1542 in the placebo group). The goal of this trial was to evaluate whether treatment with BF was effective in preventing MI injury and death in coronary artery disease patients. At 8.2 years of follow-up, there was an $18 \%$ risk reduction of major cardiac events (occurrence of cardiac death or nonfatal MI) $(p=0.02)$ [105]. Prolonged, 16 years of follow-up, showed that there was an $11 \%$ reduction $(p=0.06)$ in mortality in patients that were treated with $\mathrm{BF}$ [106-108]. BF had no therapeutic outcome on the risk of coronary heart disease and stroke in men with lower extremity arterial disease, although reduced the incidence of non-fatal coronary events in men aged 65 years or older [109].

Patients, who develop metabolic syndrome are at particularly increased risk of myocardial infarction (MI). The efficacy of BF to prevent MI was analyzed on the subgroup of patients from BIP study, who had developed metabolic syndrome (740 patients from BF group and 730 patients from the placebo group). The rate of nonfatal MI was significantly lower in patients in the BF group (9.5\% and $13.8 \%$ in BF and placebo groups, respectively; $p=0.009)$. The decrease in MI incidence in patients taking BF was reflected in a trend to a $26 \%$ reduction of cardiac mortality rate $(p=0.056)$ [110].

Existing trials are mainly directed towards the studies of lipid-lowering and anti-atherosclerotic effects of PPAR agonists, whereas the bioenergetics actions of PPAR agonists on energy metabolism in cardiomyocytes remain less investigated. Although no clinical trial has prospectively studied the effects of PPAR agonists in patients with HF, there are several compelling evidences that PPAR agonists can improve clinical outcomes in HF.

Treatment with BF in combination with ursodeoxycholic acid had a beneficial effect in patients with primary biliary cholangitis, a progressive liver disease, compared to a control group that was treated with ursodeoxycholic acid alone [111].

Studies including the cohort of six patients with the myopathic form of CPT-2 deficiency showed that six-month-long treatment with BF (200 mg three times a day) markedly upregulated CPT-2, increased oxidation rates of the long-chain fatty acids, decreased muscle pain and increased physical activity in all BF-treated patients [112]. BF failed to improve FAO in skeletal muscles and exercise tolerance in patients with CPT-2 and very long-chain acyl-CoA dehydrogenase deficiencies [92]. The authors ascribed the lack of effect FAO to the suppression of lipolysis by BF. However, an alternative explanation is that high plasma insulin in BF-treated patients had markedly inhibited lipolysis, hence hindering any increase of FAO and masking the effects of BF [113]. In vitro studies of patient cells with very long-chain acyl-CoA dehydrogenase and CPT-2 deficiencies revealed that treatment with $\mathrm{BF}$ is beneficial in cells of mildly affected patients that retain residual FAO capacities. In contrast, no increase in FAO capacities is expected in response to BF if the gene mutations impact the catalytic 
site or lead to highly unstable or severely misfolded proteins [96,114]. A phase 2 clinical trial of BF in BTHS patients (CARDIOMAN) is underway at University Hospital in Bristol, England.

\section{Conclusions}

PPARs play a central role in the pathogenesis of cardiac hypertrophy and HF and thereby, represent a potentially attractive therapeutic target for the treatment of these diseases. PPAR agonists, particularly PPAR $\alpha$ and PPAR $\beta / \delta$ agonists appear to stimulate FAO and energy metabolism in cardiomyocytes. Subsequently, improved cellular energy homeostasis in the heart attenuates systolic dysfunction in HF patients as well as in animal models of cardiomyopathy and HF. Skeletal muscle appears to be more resistant to the treatment with PPAR $\alpha$ and PPAR $\beta / \delta$ agonists. Full understanding of the therapeutic potential of PPAR agonists requires more detailed studies using various animal models of cardiac diseases. The effects of PPAR agonists on cellular transcriptional and epigenetic landscapes as well as activation/inhibition of individual PPAR isoforms on cellular metabolic and signaling systems need to be evaluated in detail using systems biology approaches.

Author Contributions: Z.K. supervised the project, edited and compiled the final version of the manuscript. Z.K. and S.J. reviewed and analyzed the literature, prepared a draft of the manuscript and proofed it. A.I.G. and A.W.S. reviewed and analyzed the literature and participated in writing the manuscript.

Funding: Studies of the authors discussed in this article were supported by the National Heart, Lung, and Blood Institute (Grants R01HL108867 to Z.K. and SC1HL118669 to S.J.), and National Institute of General Medical Sciences (Grant SC1GM128210 to S.J.) of the National Institutes of Health.

Acknowledgments: The authors apologize to all colleagues whose important studies were not cited due to space restrictions.

Conflicts of Interest: The authors declare no conflict of interest.

\section{Abbreviations}

$\begin{array}{ll}\text { AMPK } & \text { AMP kinase } \\ \text { BAT } & \text { brown adipose tissue } \\ \text { BF } & \text { bezafibrate } \\ \text { BTHS } & \text { Barth syndrome } \\ \text { CHD } & \text { coronary heart disease } \\ \text { CPT } & \text { carnitine palmitoyltransferase } \\ \text { CyP-D } & \text { cyclophilin D } \\ \text { FAO } & \text { fatty acid oxidation } \\ \text { HF } & \text { heart failure } \\ \text { MI NRF } & \text { myocardial infarction nuclear respiratory factors } \\ \text { PGC-1 } \alpha & \text { proliferator-activated receptor gamma coactivator-1 alpha } \\ \text { PPAR } & \text { peroxisome proliferator-activated receptor } \\ \text { TAC } & \text { transverse aortic constriction }\end{array}$

\section{References}

1. Schmidt, A.; Endo, N.; Rutledge, S.J.; Vogel, R.; Shinar, D.; Rodan, G.A. Identification of a new member of the steroid hormone receptor superfamily that is activated by a peroxisome proliferator and fatty acids. Mol. Endocrinol. 1992, 6, 1634-1641. [CrossRef] [PubMed]

2. Dreyer, C.; Krey, G.; Keller, H.; Givel, F.; Helftenbein, G.; Wahli, W. Control of the peroxisomal beta-oxidation pathway by a novel family of nuclear hormone receptors. Cell 1992, 68, 879-887. [CrossRef]

3. Issemann, I.; Green, S. Activation of a member of the steroid hormone receptor superfamily by peroxisome proliferators. Nature 1990, 347, 645-650. [CrossRef] [PubMed]

4. Eleff, S.; Kennaway, N.G.; Buist, N.R.; Darley-Usmar, V.M.; Capaldi, R.A.; Bank, W.J.; Chance, B. ${ }^{31}$ P NMR study of improvement in oxidative phosphorylation by vitamins $\mathrm{K} 3$ and $\mathrm{C}$ in a patient with a defect in electron transport at complex III in skeletal muscle. Proc. Natl. Acad. Sci. USA 1984, 81, 3529-3533. [CrossRef] [PubMed] 
5. Ledermann, H.; Kaufmann, B. Comparative pharmacokinetics of $400 \mathrm{mg}$ bezafibrate after a single oral administration of a new slow-release preparation and the currently available commercial form. J. Int. Med. Res. 1981, 9, 516-520. [CrossRef] [PubMed]

6. Olsson, A.G.; Lang, P.D. Dose-response study of bezafibrate on serum lipoprotein concentrations in hyperlipoproteinanemia. Atherosclerosis 1978, 31, 421-428. [CrossRef]

7. Nolte, R.T.; Wisely, G.B.; Westin, S.; Cobb, J.E.; Lambert, M.H.; Kurokawa, R.; Rosenfeld, M.G.; Willson, T.M.; Glass, C.K.; Milburn, M.V. Ligand binding and co-activator assembly of the peroxisome proliferator-activated receptor-gamma. Nature 1998, 395, 137-143. [CrossRef] [PubMed]

8. Xu, H.E.; Lambert, M.H.; Montana, V.G.; Parks, D.J.; Blanchard, S.G.; Brown, P.J.; Sternbach, D.D.; Lehmann, J.M.; Wisely, G.B.; Willson, T.M.; et al. Molecular recognition of fatty acids by peroxisome proliferator-activated receptors. Mol. Cell 1999, 3, 397-403. [CrossRef]

9. Komen, J.C.; Thorburn, D.R. Turn up the power-Pharmacological activation of mitochondrial biogenesis in mouse models. Br. J. Pharmacol. 2014, 171, 1818-1836. [CrossRef] [PubMed]

10. Lam, V.Q.; Zheng, J.; Griffin, P.R. Unique Interactome Network Signatures for Peroxisome Proliferator-activated Receptor Gamma (PPARgamma) Modulation by Functional Selective Ligands. Mol. Cell. Proteom. 2017, 16, 2098-2110. [CrossRef] [PubMed]

11. Sookoian, S.; Pirola, C.J. Elafibranor for the treatment of NAFLD: One pill, two molecular targets and multiple effects in a complex phenotype. Ann. Hepatol. 2016, 15, 604-609. [PubMed]

12. Chandra, V.; Huang, P.; Hamuro, Y.; Raghuram, S.; Wang, Y.; Burris, T.P.; Rastinejad, F. Structure of the intact PPAR-gamma-RXR-nuclear receptor complex on DNA. Nature 2008, 456, 350-356. [CrossRef] [PubMed]

13. Braissant, O.; Foufelle, F.; Scotto, C.; Dauca, M.; Wahli, W. Differential expression of peroxisome proliferator-activated receptors (PPARs): Tissue distribution of PPAR-alpha, -beta, and -gamma in the adult rat. Endocrinology 1996, 137, 354-366. [CrossRef] [PubMed]

14. Auboeuf, D.; Rieusset, J.; Fajas, L.; Vallier, P.; Frering, V.; Riou, J.P.; Staels, B.; Auwerx, J.; Laville, M.; Vidal, H. Tissue distribution and quantification of the expression of mRNAs of peroxisome proliferator-activated receptors and liver $X$ receptor-alpha in humans: No alteration in adipose tissue of obese and NIDDM patients. Diabetes 1997, 46, 1319-1327. [CrossRef] [PubMed]

15. Abbott, B.D. Review of the expression of peroxisome proliferator-activated receptors alpha (PPAR alpha), beta (PPAR beta), and gamma (PPAR gamma) in rodent and human development. Reprod. Toxicol. 2009, 27, $246-257$. [CrossRef] [PubMed]

16. Grygiel-Gorniak, B. Peroxisome proliferator-activated receptors and their ligands: Nutritional and clinical implications-A review. Nutr. J. 2014, 13, 17. [CrossRef] [PubMed]

17. Sertznig, P.; Seifert, M.; Tilgen, W.; Reichrath, J. Present concepts and future outlook: Function of peroxisome proliferator-activated receptors (PPARs) for pathogenesis, progression, and therapy of cancer. J. Cell. Physiol. 2007, 212, 1-12. [CrossRef] [PubMed]

18. Willson, T.M.; Brown, P.J.; Sternbach, D.D.; Henke, B.R. The PPARs: From orphan receptors to drug discovery. J. Med. Chem. 2000, 43, 527-550. [CrossRef] [PubMed]

19. Tenenbaum, A.; Fisman, E.Z. Balanced pan-PPAR activator bezafibrate in combination with statin: Comprehensive lipids control and diabetes prevention? Cardiovasc. Diabetol. 2012, 11, 140. [CrossRef] [PubMed]

20. Kelly, D.P.; Scarpulla, R.C. Transcriptional regulatory circuits controlling mitochondrial biogenesis and function. Genes Dev. 2004, 18, 357-368. [CrossRef] [PubMed]

21. Huss, J.M.; Kelly, D.P. Mitochondrial energy metabolism in heart failure: A question of balance. J. Clin. Investig. 2005, 115, 547-555. [CrossRef] [PubMed]

22. Ventura-Clapier, R.; Garnier, A.; Veksler, V. Transcriptional control of mitochondrial biogenesis: The central role of PGC-1alpha. Cardiovasc. Res. 2008, 79, 208-217. [CrossRef] [PubMed]

23. Zong, H.; Ren, J.M.; Young, L.H.; Pypaert, M.; Mu, J.; Birnbaum, M.J.; Shulman, G.I. AMP kinase is required for mitochondrial biogenesis in skeletal muscle in response to chronic energy deprivation. Proc. Natl. Acad. Sci. USA 2002, 99, 15983-15987. [CrossRef] [PubMed]

24. Reznick, R.M.; Shulman, G.I. The role of AMP-activated protein kinase in mitochondrial biogenesis. J. Physiol. 2006, 574, 33-39. [CrossRef] [PubMed] 
25. Jager, S.; Handschin, C.; St-Pierre, J.; Spiegelman, B.M. AMP-activated protein kinase (AMPK) action in skeletal muscle via direct phosphorylation of PGC-1alpha. Proc. Natl. Acad. Sci. USA 2007, 104, 12017-12022. [CrossRef] [PubMed]

26. Watanabe, K.; Fujii, H.; Takahashi, T.; Kodama, M.; Aizawa, Y.; Ohta, Y.; Ono, T.; Hasegawa, G.; Naito, M.; Nakajima, T.; et al. Constitutive regulation of cardiac fatty acid metabolism through peroxisome proliferator-activated receptor alpha associated with age-dependent cardiac toxicity. J. Biol. Chem. 2000, 275, 22293-22299. [CrossRef] [PubMed]

27. Campbell, F.M.; Kozak, R.; Wagner, A.; Altarejos, J.Y.; Dyck, J.R.; Belke, D.D.; Severson, D.L.; Kelly, D.P.; Lopaschuk, G.D. A role for peroxisome proliferator-activated receptor alpha (PPARalpha) in the control of cardiac malonyl-CoA levels: Reduced fatty acid oxidation rates and increased glucose oxidation rates in the hearts of mice lacking PPARalpha are associated with higher concentrations of malonyl-CoA and reduced expression of malonyl-CoA decarboxylase. J. Biol. Chem. 2002, 277, 4098-4103. [CrossRef] [PubMed]

28. Loichot, C.; Jesel, L.; Tesse, A.; Tabernero, A.; Schoonjans, K.; Roul, G.; Carpusca, I.; Auwerx, J.; Andriantsitohaina, R. Deletion of peroxisome proliferator-activated receptor-alpha induces an alteration of cardiac functions. Am. J. Physiol. Heart Circ. Physiol. 2006, 291, H161-H166. [CrossRef] [PubMed]

29. Guellich, A.; Damy, T.; Conti, M.; Claes, V.; Samuel, J.L.; Pineau, T.; Lecarpentier, Y.; Coirault, C. Tempol prevents cardiac oxidative damage and left ventricular dysfunction in the PPAR-alpha KO mouse. Am. J. Physiol. Heart Circ. Physiol. 2013, 304, H1505-H1512. [CrossRef] [PubMed]

30. Luptak, I.; Balschi, J.A.; Xing, Y.; Leone, T.C.; Kelly, D.P.; Tian, R. Decreased contractile and metabolic reserve in peroxisome proliferator-activated receptor-alpha-null hearts can be rescued by increasing glucose transport and utilization. Circulation 2005, 112, 2339-2346. [CrossRef] [PubMed]

31. Smeets, P.J.; Teunissen, B.E.; Willemsen, P.H.; van Nieuwenhoven, F.A.; Brouns, A.E.; Janssen, B.J.; Cleutjens, J.P.; Staels, B.; van der Vusse, G.J.; van Bilsen, M. Cardiac hypertrophy is enhanced in PPAR alpha-/- mice in response to chronic pressure overload. Cardiovasc. Res. 2008, 78, 79-89. [CrossRef] [PubMed]

32. Oka, S.; Alcendor, R.; Zhai, P.; Park, J.Y.; Shao, D.; Cho, J.; Yamamoto, T.; Tian, B.; Sadoshima, J. PPARalpha-Sirt1 complex mediates cardiac hypertrophy and failure through suppression of the ERR transcriptional pathway. Cell Metab. 2011, 14, 598-611. [CrossRef] [PubMed]

33. Finck, B.N.; Lehman, J.J.; Leone, T.C.; Welch, M.J.; Bennett, M.J.; Kovacs, A.; Han, X.; Gross, R.W.; Kozak, R.; Lopaschuk, G.D.; et al. The cardiac phenotype induced by PPARalpha overexpression mimics that caused by diabetes mellitus. J. Clin. Investig. 2002, 109, 121-130. [CrossRef] [PubMed]

34. Kaimoto, S.; Hoshino, A.; Ariyoshi, M.; Okawa, Y.; Tateishi, S.; Ono, K.; Uchihashi, M.; Fukai, K.; Iwai-Kanai, E.; Matoba, S. Activation of PPAR-alpha in the early stage of heart failure maintained myocardial function and energetics in pressure-overload heart failure. Am. J. Physiol. Heart Circ. Physiol. 2017, 312, H305-H313. [CrossRef] [PubMed]

35. Garnier, A.; Fortin, D.; Delomenie, C.; Momken, I.; Veksler, V.; Ventura-Clapier, R. Depressed mitochondrial transcription factors and oxidative capacity in rat failing cardiac and skeletal muscles. J. Physiol. 2003, 551, 491-501. [CrossRef] [PubMed]

36. Javadov, S.; Purdham, D.M.; Zeidan, A.; Karmazyn, M. NHE-1 inhibition improves cardiac mitochondrial function through regulation of mitochondrial biogenesis during postinfarction remodeling. Am. J. Physiol. Heart Circ. Physiol. 2006, 291, H1722-H1730. [CrossRef] [PubMed]

37. Sebastiani, M.; Giordano, C.; Nediani, C.; Travaglini, C.; Borchi, E.; Zani, M.; Feccia, M.; Mancini, M.; Petrozza, V.; Cossarizza, A.; et al. Induction of mitochondrial biogenesis is a maladaptive mechanism in mitochondrial cardiomyopathies. J. Am. Coll. Cardiol. 2007, 50, 1362-1369. [CrossRef] [PubMed]

38. Sack, M.N.; Rader, T.A.; Park, S.; Bastin, J.; McCune, S.A.; Kelly, D.P. Fatty acid oxidation enzyme gene expression is downregulated in the failing heart. Circulation 1996, 94, 2837-2842. [CrossRef] [PubMed]

39. Burns, K.A.; Vanden Heuvel, J.P. Modulation of PPAR activity via phosphorylation. Biochim. Biophys. Acta 2007, 1771, 952-960. [CrossRef] [PubMed]

40. Lazennec, G.; Canaple, L.; Saugy, D.; Wahli, W. Activation of peroxisome proliferator-activated receptors (PPARs) by their ligands and protein kinase A activators. Mol. Endocrinol. 2000, 14, 1962-1975. [CrossRef] [PubMed]

41. Barger, P.M.; Browning, A.C.; Garner, A.N.; Kelly, D.P. p38 mitogen-activated protein kinase activates peroxisome proliferator-activated receptor alpha: A potential role in the cardiac metabolic stress response. J. Biol. Chem. 2001, 276, 44495-44501. [CrossRef] [PubMed] 
42. Barger, P.M.; Brandt, J.M.; Leone, T.C.; Weinheimer, C.J.; Kelly, D.P. Deactivation of peroxisome proliferator-activated receptor-alpha during cardiac hypertrophic growth. J. Clin. Investig. 2000, 105, 1723-1730. [CrossRef] [PubMed]

43. Shalev, A.; Siegrist-Kaiser, C.A.; Yen, P.M.; Wahli, W.; Burger, A.G.; Chin, W.W.; Meier, C.A. The peroxisome proliferator-activated receptor alpha is a phosphoprotein: Regulation by insulin. Endocrinology 1996, 137, 4499-4502. [CrossRef] [PubMed]

44. Adams, M.; Reginato, M.J.; Shao, D.; Lazar, M.A.; Chatterjee, V.K. Transcriptional activation by peroxisome proliferator-activated receptor gamma is inhibited by phosphorylation at a consensus mitogen-activated protein kinase site. J. Biol. Chem. 1997, 272, 5128-5132. [CrossRef] [PubMed]

45. Lopaschuk, G.D.; Ussher, J.R.; Folmes, C.D.; Jaswal, J.S.; Stanley, W.C. Myocardial fatty acid metabolism in health and disease. Physiol. Rev. 2010, 90, 207-258. [CrossRef] [PubMed]

46. Arad, M.; Seidman, C.E.; Seidman, J.G. AMP-activated protein kinase in the heart: Role during health and disease. Circ. Res. 2007, 100, 474-488. [CrossRef] [PubMed]

47. Yoon, M.J.; Lee, G.Y.; Chung, J.J.; Ahn, Y.H.; Hong, S.H.; Kim, J.B. Adiponectin increases fatty acid oxidation in skeletal muscle cells by sequential activation of AMP-activated protein kinase, p38 mitogen-activated protein kinase, and peroxisome proliferator-activated receptor alpha. Diabetes 2006, 55, 2562-2570. [CrossRef] [PubMed]

48. Barreto-Torres, G.; Parodi-Rullan, R.; Javadov, S. The role of PPARalpha in metformin-induced attenuation of mitochondrial dysfunction in acute cardiac ischemia/reperfusion in rats. Int. J. Mol. Sci. 2012, 13, 7694-7709. [CrossRef] [PubMed]

49. Barreto-Torres, G.; Hernandez, J.S.; Jang, S.; Rodriguez-Munoz, A.R.; Torres-Ramos, C.A.; Basnakian, A.G.; Javadov, S. The beneficial effects of AMP kinase activation against oxidative stress are associated with prevention of PPARalpha-cyclophilin D interaction in cardiomyocytes. Am. J. Physiol. Heart Circ. Physiol. 2015, 308, H749-H758. [CrossRef] [PubMed]

50. Barreto-Torres, G.; Javadov, S. Possible Role of Interaction between PPARalpha and Cyclophilin D in Cardioprotection of AMPK against In Vivo Ischemia-Reperfusion in Rats. PPAR Res. 2016, 2016, 9282087. [CrossRef] [PubMed]

51. Duan, S.Z.; Ivashchenko, C.Y.; Russell, M.W.; Milstone, D.S.; Mortensen, R.M. Cardiomyocyte-specific knockout and agonist of peroxisome proliferator-activated receptor-gamma both induce cardiac hypertrophy in mice. Circ. Res. 2005, 97, 372-379. [CrossRef] [PubMed]

52. Barbieri, M.; Di Filippo, C.; Esposito, A.; Marfella, R.; Rizzo, M.R.; D’Amico, M.; Ferraraccio, F.; Di Ronza, C.; Duan, S.Z.; Mortensen, R.M.; et al. Effects of PPARs agonists on cardiac metabolism in littermate and cardiomyocyte-specific PPAR-gamma-knockout (CM-PGKO) mice. PLoS ONE 2012, 7, e35999. [CrossRef] [PubMed]

53. Luo, J.; Wu, S.; Liu, J.; Li, Y.; Yang, H.; Kim, T.; Zhelyabovska, O.; Ding, G.; Zhou, Y.; Yang, Y.; et al. Conditional PPARgamma knockout from cardiomyocytes of adult mice impairs myocardial fatty acid utilization and cardiac function. Am. J. Transl. Res. 2010, 3, 61-72. [PubMed]

54. Ding, G.; Fu, M.; Qin, Q.; Lewis, W.; Kim, H.W.; Fukai, T.; Bacanamwo, M.; Chen, Y.E.; Schneider, M.D.; Mangelsdorf, D.J.; et al. Cardiac peroxisome proliferator-activated receptor gamma is essential in protecting cardiomyocytes from oxidative damage. Cardiovasc. Res. 2007, 76, 269-279. [CrossRef] [PubMed]

55. Son, N.H.; Park, T.S.; Yamashita, H.; Yokoyama, M.; Huggins, L.A.; Okajima, K.; Homma, S.; Szabolcs, M.J.; Huang, L.S.; Goldberg, I.J. Cardiomyocyte expression of PPARgamma leads to cardiac dysfunction in mice. J. Clin. Investig. 2007, 117, 2791-2801. [CrossRef] [PubMed]

56. Liu, J.; Wang, P.; Luo, J.; Huang, Y.; He, L.; Yang, H.; Li, Q.; Wu, S.; Zhelyabovska, O.; Yang, Q. Peroxisome proliferator-activated receptor beta/delta activation in adult hearts facilitates mitochondrial function and cardiac performance under pressure-overload condition. Hypertension 2011, 57, 223-230. [CrossRef] [PubMed] 
57. Jucker, B.M.; Doe, C.P.; Schnackenberg, C.G.; Olzinski, A.R.; Maniscalco, K.; Williams, C.; Hu, T.C.; Lenhard, S.C.; Costell, M.; Bernard, R.; et al. PPARdelta activation normalizes cardiac substrate metabolism and reduces right ventricular hypertrophy in congestive heart failure. J. Cardiovasc. Pharmacol. 2007, 50, 25-34. [CrossRef] [PubMed]

58. Pol, C.J.; Lieu, M.; Drosatos, K. PPARs: Protectors or Opponents of Myocardial Function? PPAR Res. 2015, 2015, 835985. [CrossRef] [PubMed]

59. Parodi-Rullan, R.M.; Chapa-Dubocq, X.R.; Javadov, S. Acetylation of Mitochondrial Proteins in the Heart: The Role of SIRT3. Front. Physiol. 2018, 9, 1094. [CrossRef] [PubMed]

60. Jiang, X.; Ye, X.; Guo, W.; Lu, H.; Gao, Z. Inhibition of HDAC3 promotes ligand-independent PPARgamma activation by protein acetylation. J. Mol. Endocrinol. 2014, 53, 191-200. [CrossRef] [PubMed]

61. Montgomery, R.L.; Potthoff, M.J.; Haberland, M.; Qi, X.; Matsuzaki, S.; Humphries, K.M.; Richardson, J.A.; Bassel-Duby, R.; Olson, E.N. Maintenance of cardiac energy metabolism by histone deacetylase 3 in mice. J. Clin. Investig. 2008, 118, 3588-3597. [CrossRef] [PubMed]

62. Diezko, R.; Suske, G. Ligand binding reduces SUMOylation of the peroxisome proliferator-activated receptor gamma (PPARgamma) activation function 1 (AF1) domain. PLoS ONE 2013, 8, e66947. [CrossRef] [PubMed]

63. Kim, J.H.; Park, K.W.; Lee, E.W.; Jang, W.S.; Seo, J.; Shin, S.; Hwang, K.A.; Song, J. Suppression of PPARgamma through MKRN1-mediated ubiquitination and degradation prevents adipocyte differentiation. Cell Death Differ. 2014, 21, 594-603. [CrossRef] [PubMed]

64. Rodriguez, J.E.; Liao, J.Y.; He, J.; Schisler, J.C.; Newgard, C.B.; Drujan, D.; Glass, D.J.; Frederick, C.B.; Yoder, B.C.; Lalush, D.S.; et al. The ubiquitin ligase MuRF1 regulates PPARalpha activity in the heart by enhancing nuclear export via monoubiquitination. Mol. Cell. Endocrinol. 2015, 413, 36-48. [CrossRef] [PubMed]

65. Qian, Y.; Li, P.; Zhang, J.; Shi, Y.; Chen, K.; Yang, J.; Wu, Y.; Ye, X. Association between peroxisome proliferator-activated receptor-alpha, delta, and gamma polymorphisms and risk of coronary heart disease: A case-control study and meta-analysis. Medicine (Baltimore) 2016, 95, e4299. [CrossRef] [PubMed]

66. Rudkowska, I.; Verreault, M.; Barbier, O.; Vohl, M.C. Differences in transcriptional activation by the two allelic (L162V Polymorphic) variants of PPARalpha after Omega-3 fatty acids treatment. PPAR Res. 2009, 2009, 369602. [CrossRef] [PubMed]

67. Tai, E.S.; Corella, D.; Demissie, S.; Cupples, L.A.; Coltell, O.; Schaefer, E.J.; Tucker, K.L.; Ordovas, J.M. Polyunsaturated fatty acids interact with the PPARA-L162V polymorphism to affect plasma triglyceride and apolipoprotein C-III concentrations in the Framingham Heart Study. J. Nutr. 2005, 135, 397-403. [CrossRef] [PubMed]

68. Reinhard, W.; Stark, K.; Sedlacek, K.; Fischer, M.; Baessler, A.; Neureuther, K.; Weber, S.; Kaess, B.; Wiedmann, S.; Mitsching, S.; et al. Association between PPARalpha gene polymorphisms and myocardial infarction. Clin. Sci. (Lond.) 2008, 115, 301-308. [CrossRef] [PubMed]

69. Ingwall, J.S. Energy metabolism in heart failure and remodelling. Cardiovasc. Res. 2009, 81, $412-419$. [CrossRef] [PubMed]

70. Neubauer, S. The failing heart-An engine out of fuel. N. Engl. J. Med. 2007, 356, 1140-1151. [CrossRef] [PubMed]

71. Stanley, W.C.; Recchia, F.A.; Lopaschuk, G.D. Myocardial substrate metabolism in the normal and failing heart. Physiol. Rev. 2005, 85, 1093-1129. [CrossRef] [PubMed]

72. Xiong, D.; He, H.; James, J.; Tokunaga, C.; Powers, C.; Huang, Y.; Osinska, H.; Towbin, J.A.; Purevjav, E.; Balschi, J.A.; et al. Cardiac-specific VLCAD deficiency induces dilated cardiomyopathy and cold intolerance. Am. J. Physiol. Heart Circ. Physiol. 2014, 306, H326-H338. [CrossRef] [PubMed]

73. Exil, V.J.; Gardner, C.D.; Rottman, J.N.; Sims, H.; Bartelds, B.; Khuchua, Z.; Sindhal, R.; Ni, G.; Strauss, A.W. Abnormal mitochondrial bioenergetics and heart rate dysfunction in mice lacking very-long-chain acyl-CoA dehydrogenase. Am. J. Physiol. Heart Circ. Physiol. 2006, 290, H1289-H1297. [CrossRef] [PubMed]

74. Wu, J.; Song, Y.; Li, H.; Chen, J. Rhabdomyolysis associated with fibrate therapy: Review of 76 published cases and a new case report. Eur. J. Clin. Pharmacol. 2009, 65, 1169-1174. [CrossRef] [PubMed]

75. Lebrasseur, N.K.; Duhaney, T.A.; De Silva, D.S.; Cui, L.; Ip, P.C.; Joseph, L.; Sam, F. Effects of fenofibrate on cardiac remodeling in aldosterone-induced hypertension. Hypertension 2007, 50, 489-496. [CrossRef] [PubMed] 
76. Brigadeau, F.; Gele, P.; Wibaux, M.; Marquie, C.; Martin-Nizard, F.; Torpier, G.; Fruchart, J.C.; Staels, B.; Duriez, P.; Lacroix, D. The PPARalpha activator fenofibrate slows down the progression of the left ventricular dysfunction in porcine tachycardia-induced cardiomyopathy. J. Cardiovasc. Pharmacol. 2007, 49, 408-415. [CrossRef] [PubMed]

77. Labinskyy, V.; Bellomo, M.; Chandler, M.P.; Young, M.E.; Lionetti, V.; Qanud, K.; Bigazzi, F.; Sampietro, T.; Stanley, W.C.; Recchia, F.A. Chronic activation of peroxisome proliferator-activated receptor-alpha with fenofibrate prevents alterations in cardiac metabolic phenotype without changing the onset of decompensation in pacing-induced heart failure. J. Pharmacol. Exp. Ther. 2007, 321, 165-171. [CrossRef] [PubMed]

78. Ichihara, S.; Obata, K.; Yamada, Y.; Nagata, K.; Noda, A.; Ichihara, G.; Yamada, A.; Kato, T.; Izawa, H.; Murohara, T.; et al. Attenuation of cardiac dysfunction by a PPAR-alpha agonist is associated with down-regulation of redox-regulated transcription factors. J. Mol. Cell. Cardiol. 2006, 41, 318-329. [CrossRef] [PubMed]

79. Ogata, T.; Miyauchi, T.; Sakai, S.; Irukayama-Tomobe, Y.; Goto, K.; Yamaguchi, I. Stimulation of peroxisome-proliferator-activated receptor alpha (PPAR alpha) attenuates cardiac fibrosis and endothelin-1 production in pressure-overloaded rat hearts. Clin. Sci. (Lond.) 2002, 103 (Suppl. 48), 284S-288S. [CrossRef] [PubMed]

80. Duhaney, T.A.; Cui, L.; Rude, M.K.; Lebrasseur, N.K.; Ngoy, S.; De Silva, D.S.; Siwik, D.A.; Liao, R.; Sam, F. Peroxisome proliferator-activated receptor alpha-independent actions of fenofibrate exacerbates left ventricular dilation and fibrosis in chronic pressure overload. Hypertension 2007, 49, 1084-1094. [CrossRef] [PubMed]

81. Hafstad, A.D.; Khalid, A.M.; Hagve, M.; Lund, T.; Larsen, T.S.; Severson, D.L.; Clarke, K.; Berge, R.K.; Aasum, E. Cardiac peroxisome proliferator-activated receptor-alpha activation causes increased fatty acid oxidation, reducing efficiency and post-ischaemic functional loss. Cardiovasc. Res. 2009, 83, 519-526. [CrossRef] [PubMed]

82. Linz, W.; Wohlfart, P.; Baader, M.; Breitschopf, K.; Falk, E.; Schafer, H.L.; Gerl, M.; Kramer, W.; Rutten, H. The peroxisome proliferator-activated receptor-alpha (PPAR-alpha) agonist, AVE8134, attenuates the progression of heart failure and increases survival in rats. Acta Pharmacol. Sin. 2009, 30, 935-946. [CrossRef] [PubMed]

83. Schafer, H.L.; Linz, W.; Falk, E.; Glien, M.; Glombik, H.; Korn, M.; Wendler, W.; Herling, A.W.; Rutten, H. AVE8134, a novel potent PPARalpha agonist, improves lipid profile and glucose metabolism in dyslipidemic mice and type 2 diabetic rats. Acta Pharmacol. Sin. 2012, 33, 82-90. [CrossRef] [PubMed]

84. Forman, B.M.; Chen, J.; Evans, R.M. Hypolipidemic drugs, polyunsaturated fatty acids, and eicosanoids are ligands for peroxisome proliferator-activated receptors alpha and delta. Proc. Natl. Acad. Sci. USA 1997, 94, 4312-4317. [CrossRef] [PubMed]

85. Lam, V.H.; Zhang, L.; Huqi, A.; Fukushima, A.; Tanner, B.A.; Onay-Besikci, A.; Keung, W.; Kantor, P.F.; Jaswal, J.S.; Rebeyka, I.M.; et al. Activating PPARalpha Prevents Post-Ischemic Contractile Dysfunction in Hypertrophied Neonatal Hearts. Circ. Res. 2015. [CrossRef] [PubMed]

86. Kliewer, S.A.; Sundseth, S.S.; Jones, S.A.; Brown, P.J.; Wisely, G.B.; Koble, C.S.; Devchand, P.; Wahli, W.; Willson, T.M.; Lenhard, J.M.; et al. Fatty acids and eicosanoids regulate gene expression through direct interactions with peroxisome proliferator-activated receptors alpha and gamma. Proc. Natl. Acad. Sci. USA 1997, 94, 4318-4323. [CrossRef] [PubMed]

87. Brown, P.J.; Winegar, D.A.; Plunket, K.D.; Moore, L.B.; Lewis, M.C.; Wilson, J.G.; Sundseth, S.S.; Koble, C.S.; $\mathrm{Wu}, \mathrm{Z}$.; Chapman, J.M.; et al. A ureido-thioisobutyric acid (GW9578) is a subtype-selective PPARalpha agonist with potent lipid-lowering activity. J. Med. Chem. 1999, 42, 3785-3788. [CrossRef] [PubMed]

88. Olsson, A.G.; Lang, P.D. One-year study of the effect of bezafibrate on serum lipoprotein concentrations in hyperlipoproteinaemia. Atherosclerosis 1978, 31, 429-433. [CrossRef]

89. Jonkers, I.J.; de Man, F.H.; van der Laarse, A.; Frolich, M.; Gevers Leuven, J.A.; Kamper, A.M.; Blauw, G.J.; Smelt, A.H. Bezafibrate reduces heart rate and blood pressure in patients with hypertriglyceridemia. J. Hypertens. 2001, 19, 749-755. [CrossRef] [PubMed]

90. Peters, J.M.; Aoyama, T.; Burns, A.M.; Gonzalez, F.J. Bezafibrate is a dual ligand for PPARalpha and PPARbeta: Studies using null mice. Biochim. Biophys. Acta 2003, 1632, 80-89. [CrossRef] 
91. Yamaguchi, S.; Li, H.; Purevsuren, J.; Yamada, K.; Furui, M.; Takahashi, T.; Mushimoto, Y.; Kobayashi, H.; Hasegawa, Y.; Taketani, T.; et al. Bezafibrate can be a new treatment option for mitochondrial fatty acid oxidation disorders: Evaluation by in vitro probe acylcarnitine assay. Mol. Genet. Metab. 2012, 107, 87-91. [CrossRef] [PubMed]

92. Orngreen, M.C.; Madsen, K.L.; Preisler, N.; Andersen, G.; Vissing, J.; Laforet, P. Bezafibrate in skeletal muscle fatty acid oxidation disorders: A randomized clinical trial. Neurology 2014, 82, 607-613. [CrossRef] [PubMed]

93. Dillon, L.M.; Hida, A.; Garcia, S.; Prolla, T.A.; Moraes, C.T. Long-term bezafibrate treatment improves skin and spleen phenotypes of the mtDNA mutator mouse. PLoS ONE 2012, 7, e44335. [CrossRef] [PubMed]

94. Dumont, M.; Stack, C.; Elipenahli, C.; Jainuddin, S.; Gerges, M.; Starkova, N.; Calingasan, N.Y.; Yang, L.; Tampellini, D.; Starkov, A.A.; et al. Bezafibrate administration improves behavioral deficits and tau pathology in P301S mice. Hum. Mol. Genet. 2012, 21, 5091-5105. [CrossRef] [PubMed]

95. Huang, Y.; Powers, C.; Moore, V.; Schafer, C.; Ren, M.; Phoon, C.K.; James, J.F.; Glukhov, A.V.; Javadov, S.; Vaz, F.M.; et al. The PPAR pan-agonist bezafibrate ameliorates cardiomyopathy in a mouse model of Barth syndrome. Orphanet J. Rare Dis. 2017, 12, 49. [CrossRef] [PubMed]

96. Djouadi, F.; Bastin, J. PPARs as therapeutic targets for correction of inborn mitochondrial fatty acid oxidation disorders. J. Inherit. Metab. Dis. 2008, 31, 217-225. [CrossRef] [PubMed]

97. Nakajima, T.; Tanaka, N.; Kanbe, H.; Hara, A.; Kamijo, Y.; Zhang, X.; Gonzalez, F.J.; Aoyama, T. Bezafibrate at clinically relevant doses decreases serum/liver triglycerides via down-regulation of sterol regulatory element-binding protein-1c in mice: A novel peroxisome proliferator-activated receptor alpha-independent mechanism. Mol. Pharmacol. 2009, 75, 782-792. [CrossRef] [PubMed]

98. Viscomi, C.; Bottani, E.; Civiletto, G.; Cerutti, R.; Moggio, M.; Fagiolari, G.; Schon, E.A.; Lamperti, C.; Zeviani, M. In vivo correction of COX deficiency by activation of the AMPK/PGC-1alpha axis. Cell Metab. 2011, 14, 80-90. [CrossRef] [PubMed]

99. Johri, A.; Calingasan, N.Y.; Hennessey, T.M.; Sharma, A.; Yang, L.; Wille, E.; Chandra, A.; Beal, M.F. Pharmacologic activation of mitochondrial biogenesis exerts widespread beneficial effects in a transgenic mouse model of Huntington's disease. Hum. Mol. Genet. 2012, 21, 1124-1137. [CrossRef] [PubMed]

100. Sugihara, J.; Imamura, T.; Nagafuchi, S.; Bonaventura, J.; Bonaventura, C.; Cashon, R. Hemoglobin Rahere, a human hemoglobin variant with amino acid substitution at the 2,3-diphosphoglycerate binding site. Functional consequences of the alteration and effects of bezafibrate on the oxygen bindings. J. Clin. Investig. 1985, 76, 1169-1173. [CrossRef] [PubMed]

101. Shibayama, N.; Miura, S.; Tame, J.R.; Yonetani, T.; Park, S.Y. Crystal structure of horse carbonmonoxyhemoglobin-bezafibrate complex at 1.55-A resolution. A novel allosteric binding site in R-state hemoglobin. J. Biol. Chem. 2002, 277, 38791-38796. [CrossRef] [PubMed]

102. Schafer, C.; Moore, V.; Dasgupta, N.; Javadov, S.; James, J.F.; Glukhov, A.I.; Strauss, A.W.; Khuchua, Z. The Effects of PPAR Stimulation on Cardiac Metabolic Pathways in Barth Syndrome Mice. Front. Pharmacol. 2018, 9, 318. [CrossRef] [PubMed]

103. Jakob, T.; Nordmann, A.J.; Schandelmaier, S.; Ferreira-Gonzalez, I.; Briel, M. Fibrates for primary prevention of cardiovascular disease events. Cochrane Database Syst. Rev. 2016, 11, CD009753. [CrossRef] [PubMed]

104. Wang, D.; Liu, B.; Tao, W.; Hao, Z.; Liu, M. Fibrates for secondary prevention of cardiovascular disease and stroke. Cochrane Database Syst. Rev. 2015, CD009580. [CrossRef] [PubMed]

105. Goldenberg, I.; Benderly, M.; Goldbourt, U. Secondary prevention with bezafibrate therapy for the treatment of dyslipidemia: An extended follow-up of the BIP trial. J. Am. Coll. Cardiol. 2008, 51, 459-465. [CrossRef] [PubMed]

106. Goldenberg, I.; Boyko, V.; Tennenbaum, A.; Tanne, D.; Behar, S.; Guetta, V. Long-term benefit of high-density lipoprotein cholesterol-raising therapy with bezafibrate: 16-year mortality follow-up of the bezafibrate infarction prevention trial. Arch. Intern. Med. 2009, 169, 508-514. [CrossRef] [PubMed]

107. Goldenberg, I.; Benderly, M.; Sidi, R.; Boyko, V.; Tenenbaum, A.; Tanne, D.; Behar, S. Relation of clinical benefit of raising high-density lipoprotein cholesterol to serum levels of low-density lipoprotein cholesterol in patients with coronary heart disease (from the Bezafibrate Infarction Prevention Trial). Am. J. Cardiol. 2009, 103, 41-45. [CrossRef] [PubMed]

108. Arbel, Y.; Klempfner, R.; Erez, A.; Goldenberg, I.; Benzekry, S.; Shlomo, N.; Fisman, E.Z.; Tenenbaum, A. Bezafibrate for the treatment of dyslipidemia in patients with coronary artery disease: 20-year mortality follow-up of the BIP randomized control trial. Cardiovasc. Diabetol. 2016, 15, 11. [CrossRef] [PubMed] 
109. Meade, T.; Zuhrie, R.; Cook, C.; Cooper, J. Bezafibrate in men with lower extremity arterial disease: Randomised controlled trial. BMJ 2002, 325, 1139. [CrossRef] [PubMed]

110. Tenenbaum, A.; Motro, M.; Fisman, E.Z.; Tanne, D.; Boyko, V.; Behar, S. Bezafibrate for the secondary prevention of myocardial infarction in patients with metabolic syndrome. Arch. Intern. Med. 2005, 165, 1154-1160. [CrossRef] [PubMed]

111. Corpechot, C.; Chazouilleres, O.; Rousseau, A.; Le Gruyer, A.; Habersetzer, F.; Mathurin, P.; Goria, O.; Potier, P.; Minello, A.; Silvain, C.; et al. A Placebo-Controlled Trial of Bezafibrate in Primary Biliary Cholangitis. N. Engl. J. Med. 2018, 378, 2171-2181. [CrossRef] [PubMed]

112. Bonnefont, J.P.; Bastin, J.; Laforet, P.; Aubey, F.; Mogenet, A.; Romano, S.; Ricquier, D.; Gobin-Limballe, S.; Vassault, A.; Behin, A.; et al. Long-term follow-up of bezafibrate treatment in patients with the myopathic form of carnitine palmitoyltransferase 2 deficiency. Clin. Pharmacol. Ther. 2010, 88, 101-108. [CrossRef] [PubMed]

113. Bastin, J.; Bonnefont, J.P.; Djouadi, F.; Bresson, J.L. Should the beneficial impact of bezafibrate on fatty acid oxidation disorders be questioned? J. Inherit. Metab. Dis. 2014, 38, 371-372. [CrossRef] [PubMed]

114. Gobin-Limballe, S.; McAndrew, R.P.; Djouadi, F.; Kim, J.J.; Bastin, J. Compared effects of missense mutations in Very-Long-Chain Acyl-CoA Dehydrogenase deficiency: Combined analysis by structural, functional and pharmacological approaches. Biochim. Biophys. Acta 2010, 1802, 478-484. [CrossRef] [PubMed]

(C) 2018 by the authors. Licensee MDPI, Basel, Switzerland. This article is an open access article distributed under the terms and conditions of the Creative Commons Attribution (CC BY) license (http:/ / creativecommons.org/licenses/by/4.0/). 